\title{
Evaluation of Cherry Tomato (Solanum Lycopersicum L. var. cerasiforme) Genotypes for Growth and Yield Parameters
}

\author{
Najibullah Anwarzai*, Jyothi Kattegoudar, M. Anjanappa, Meenakshi Sood, \\ B. Anjaneya Reddy and S. Mohan Kumar \\ Department of vegetable science College of Horticulture, UHS campus, GKVK, \\ Bengaluru-560065, India \\ *Corresponding author
}

\begin{tabular}{|l|}
\hline Ke y w o r d s \\
$\begin{array}{l}\text { Genotypes, } \\
\text { plant height, } \\
\text { cluster }\end{array}$ \\
Article Info \\
\hline $\begin{array}{l}\text { Accepted: } \\
\text { 05 February } 2020 \\
\text { Available Online: } \\
\text { 10 March } 2020\end{array}$ \\
\hline
\end{tabular}

\section{A B S T R A C T}

An experiment entitled Evaluation of cherry tomato (Solanum lycopersicum L. var. cerasiforme) genotypes for growth and yield parameters was conducted in the Department of Vegetable Science, College of Horticulture, Bengaluru, Karnataka during the year 2018-19. In present study, twenty one cherry tomato genotypes were evaluated for growth, and yield parameters. Among different genotypes, COHBT-199 genotype recorded maximum plant height $(261.10 \mathrm{~cm})$ and minimum height was recorded in COHBT-206 $(179.50 \mathrm{~cm})$. Genotype COHBT-199, COHBT-27 and COHBT-70 recorded maximum number of branches per plant (23.80) and minimum was recorded in COHBT -198 (20.50). Earliness reported in COHBT-199 (24.00 days) and maximum was recorded in COHBT-217 (32.50 days). COHHT-199 genotype recorded maximum number of flowers per cluster (10.64) and number of fruits per cluster (8.75) and minimum number of fruits per cluster was recorded in COHBT-191 (3.00).Among different cherry tomato genotypes, maximum fruit length was recorded in COHBT-198 $(5.00 \mathrm{~cm})$. The maximum fruit girth $(4.00 \mathrm{~cm})$ was recorded in COHBT-209, COHBT-198 and COHBT-208. Genotype COHBT-198 recorded maximum average fruit weight (43.90 g). The maximum fruit yield per plant was recorded in genotype COHBT$198(2.30 \mathrm{~kg})$.

\section{Introduction}

Tomato (Solanum lycopresicum L.) is one of the most important solanaceous vegetable crops grown widely all over the world and is native to South America (Rick, 1969). Botanically cherry tomato is called Solanum lycopersicum var. cerasiforme having chromosome number $2 \mathrm{n}=24$. It is thought to be the ancestor of all cultivated tomatoes. It is widely cultivated in Central America and is distributed in California, Korea, Germany, Mexico and Florida. It is a warm season crop reasonably tolerant to heat and drought and 
grows under wide range of soil and climatic conditions. (Anon., 2009a) Cherry tomato is grown for its edible fruits which can be consumed either fresh as a salad of after cooking as snacks. They are perfect for making processed products like sauce, soup, ketchup, puree, curries, paste, powder and sandwich. Unripe green fruit are used for preparation of pickles and chutney. The fruit size range from thumb tip to the size of a golf ball and can range from being spherical to slightly oblong in shape (Anon., 2009b).

\section{Materials and Methods}

An experiment was carried out to study Evaluation of cherry tomato (Solanum lycopersicum L. var. cerasiforme) genotypes for growth and yield was under taken during Jun2018 (Kharif season)at Department of Vegetable Science, College of Horticulture Bengaluru, University of Horticultural Sciences, Bagalkot. The experiment site is located at an of 930 meters above mean sea level (MSL) at $12.97^{\circ} \mathrm{N}$ latitude and $77.56^{\circ} \mathrm{E}$ longitudes in the Eastern Dry Zone of Karnataka (Zone-V).

\section{Nursery and agronomic practices}

Cherry tomato seeds were sown in plastic protrays having 98 cells. Regular irrigation and plant production measure were taken to raise the good quality seedlings using growing media like mixture of coco peat and farm yard manure in 2:1 ratio. pro-trays are kept in green house.

\section{Field preparation and transplanting}

During July 2018, field was brought to fine tilth by ploughing and harrowing. Farm yard manure was incorporated to the soil and bed covered by plastic mulch. The 25 days old seedling were transplanted at the spacing of $90 \mathrm{~cm} \times 60 \mathrm{~cm}$. The experiment plots were kept free from weeds by hand weeding at frequent interval. All agronomic practices were taken as per the recommendations of package of practices of University of Horticultural Sciences, Bagalkot.

\section{Plant height}

Plant height was measured in centimeters from the ground level to the tip of the plant at 30, 60, 90 and 120 day after transplanting (DAT) was expressed in centimeters.

\section{Number of branches per plant}

Number of branches per plant were counted at 30, 60, 90 and 120 day after transplanting (DAT).

\section{Days to 50 per cent flowering}

Number of days taken from the date of transplanting to first flower appearance in 50 percentage of the plant population in each replication was recorded and the average was computed.

\section{Number of flowers per cluster}

Three clusters per plant were taken from five tagged plants in each replication and number of flowers in each cluster was counted at full bloom. Then the average number of flowers per cluster was calculated.

\section{Number of fruits per cluster}

Before first picking, three fruit bunches were chosen at random in five tagged plant in both the replications to calculate the average number of fruits per cluster.

\section{Fruit length (cm)}

Five randomly selected fruits of each genotype in each replications were measured 
for fruit length $(\mathrm{cm})$ at peak fruiting with the help of vernier caliper and the average was calculated.

\section{Fruit girth (cm)}

Five randomly selected fruits from five tagged plants of each genotype from each replication were measured for fruit girth $(\mathrm{cm})$ at peak fruiting with the help of vernier caliper and the average was calculated.

\section{Average fruit weight (g)}

Average fruit weight was calculated by adding weight of ten randomly selected fruits from each of tagged plants and it was computed by using following formula.

$$
\text { Average fruit weight }=\frac{\text { Total fruit weight }}{\text { Total no. } \text { of fruits }}
$$

\section{Fruit yield per plant (kg)}

Total weight of fruits harvested from five tagged plants of all the pickings were added and average yield per plant was worked out and expressed in kilograms per plant (kg/plant).

\section{Results and Discussion}

\section{Plant height}

Plant height is an indication of plant health, it's robustness and determines the number of branches and foliage. Better the plant height better exposure of plant to solar interception of canopy and better biomass accumulation and translocation.

Plant height showed significant at 30 DAP 60, 90 and 120 DAP resulted significant difference among genotypes. Plant height ranged from $98.50 \mathrm{~cm}$ to $180.20 \mathrm{~cm}, 156.80 \mathrm{~cm}$ to $243.00 \mathrm{~cm}$ and $179.50 \mathrm{~cm}$ to $261.10 \mathrm{~cm}$ at 60, 90 and 120 DAP respectively.

These results were in concurrence with the earlier findings of Nitzsche et al., (2003), Kumar et al., (2014) and Renuka et al., (2014) in cherry tomato.These indeterminate growth habits are mainly preferred because of their longer harvest duration Prema et al., (2011a).

\section{Number of branches per plant}

Number of branches per plant ranged from 4.30 to $11.70,11.10$ to $15.30,18.20$ to 22.00 and 20.90 to 23.80at 30, 60, 90 and 120 DAP respectively. More number of branches results in more production of leaves, the size of the leaf and number of leaves which decides the efficiency of photosynthesis activity which contributed towards better translocation efficiency lead to better growth and yield.

Mahendrakar et al., (2006) and Gomathi (2008) also observed the similar result of more number of branches per plant in tomato. Such information on variation in number of primary branches per plant was also available from the studies of Kumar et al., (2014) and Renuka et al., (2014) in cherry tomato.

\section{Days of 50 per cent of flowering DAP}

The data with respect to days of 50 per cent of flowering did not vary significantly among different cherry tomato genotypes. A numerically maximum day of 50 per cent of flowering was recorded in COHBT- 217 (32.50 days) which was on par with COHBT46, COHBT- 27 and COHBT- 270 (32.00 days) and minimum of recorded in COHBT199 (24.00 days). Such earliness could be due to its higher capacity to make available assimilates to the apex during the sensitive phase before initiation Prema et al., (2011a) and Alam et al., (2014). 


\section{Number of flowers per cluster}

Development of genotypes with more number of flowers per cluster and more number of clusters per plant helps to increase the yield through more fruits per plant. The maximum number of flowers per cluster was observed in COHHT-199 (10.64) which was followed by COHBT-198 (9.75) and minimum was observed in COHBT- 191 (5.60). These results were in concurrence with the earlier findings Renuka et al., (2014) in cherry tomato.

\section{Number of fruits per cluster}

This might be due to the prevalence of micro climate with better environmental condition with optimum temperature would helped in the better pollination and ultimately leads to fruit set. The maximum number of fruits per cluster was recorded in COHBT (8.75) and minimum was recorded in COHBT-191 (3.00). The results are similar with Singh et al., (2000) reported number of fruits per cluster ranged from 4.30 to 8.70 with over all mean of 5.90 and Mohanty (2003), Prashanth (2003), Mehta and Asati (2008) and Prema et al., (2011a) also reported similar results.

\section{Fruit length}

Significantly maximum fruit length was observed in fruit length showed significant differences among the different cherry tomato genotypes.The maximum fruit length was observed in COHBT- $198(5.00 \mathrm{~cm})$ which was followed by COHBT- $36(4.05 \mathrm{~cm})$ and minimum was observed in COHBT- 262 $(1.75 \mathrm{~cm})$. The shorter fruit length of cherry tomato genotypes may due to character of cerasiforme species. The present result correlates with the outcome of Kumar et al., (2014) in cherry tomato. Similar finding have been reported by Trivedi (1996), Naidu (2001), Ghosh et al., (2010), Kaushik et al.,
(2011), Prema et al., (2011), Islam et al., (2012) and Manna and Paul (2012).

\section{Fruit girth}

The shorter fruit girth of cherry tomato genotypes may due to character of cerasiforme species. The present result correlates with the outcome of Kumar et al., (2014) in cherry tomato. Significantly maximum fruit girth $(4.00 \mathrm{~cm})$ was observed in COHBT- 209, COHBT- 198 and COHBT208 which was on par COHBT- $206(3.90 \mathrm{~cm})$ and minimum was observed in COHBT- 262 $(1.65 \mathrm{~cm})$. Similar finding have been reported by Trivedi (1996), Naidu (2001), Ghosh et al., (2010), Kaushik et al., (2011), Prema et al., (2011), Islam et al., (2012) and Manna and Paul (2012).

\section{Average fruit weight}

Significant differences among the different cherry tomato genotypes are presented in. The maximum average fruit weight was observed in COHBT-198 (43.90g) which was followed by COHBT-70 (38.90g) and minimum was observed in COHBT- 262 (3.50g).This variation in average fruit weight might be due to inverse relationship existing between average fruit weight, and number of fruits per cluster. This was conformity with the findings of Renuka et al., (2017).

\section{Fruit yield per plant}

The average fruit weight directly contributes towards the fruit yield per plant. This was in agreement with the finding of Deepa and Thakur (2008) in tomato. The fruit yield per plant showed significant differences among the different cherry tomato genotypes. The maximum fruit yield per plant was recorded in COHBT-198 $(2.30 \mathrm{~kg})$ which was followed by COHBT- $70(2.20 \mathrm{~kg})$ and minimum was recorded in COHBT- $270(1.00 \mathrm{~kg})$. 
Table.1 Variation of cherry tomato genotypes for growth parameters

\begin{tabular}{|c|c|c|c|c|c|c|c|c|c|c|}
\hline \multirow[t]{2}{*}{ Treatment } & \multirow[t]{2}{*}{ Genotypes } & \multicolumn{4}{|c|}{ Plant height (cm) } & \multicolumn{4}{|c|}{ Number of branch par plant } & \multirow{2}{*}{$\begin{array}{l}\text { Days to } 50 \\
\text { \% flowering }\end{array}$} \\
\hline & & 30 DAP & 60 DAP & 90 DAP & 120 DAP & 30 DAP & 60 DAP & 90 DAP & 120 DAP & \\
\hline $\mathbf{T}_{1}$ & COHBT-253 & $69.10^{\text {defgh }}$ & $135.80^{\mathrm{gh}}$ & $183.40^{\text {cde }}$ & $198.10^{\mathrm{fgh}}$ & $4.30^{\mathrm{e}}$ & $11.60^{\mathrm{ef}}$ & $18.20^{\mathrm{i}}$ & $21.50^{\text {bcdef }}$ & 31.00 \\
\hline $\mathbf{T}_{2}$ & COHBT -46 & $66.30^{\mathrm{def}}$ & $161.00^{\mathrm{cd}}$ & $233.70^{\mathrm{ab}}$ & $245.10^{\text {bcd }}$ & $6.20^{\mathrm{de}}$ & $11.10^{\mathrm{f}}$ & $20.40^{\mathrm{bc}}$ & $22.40^{\text {ebcde }}$ & 32.00 \\
\hline $\mathbf{T}_{\mathbf{3}}$ & COHBT-27 & $74.80^{\text {bcd }}$ & $141.60^{\mathrm{efg}}$ & $193.30^{c}$ & $207.10^{\mathrm{ef}}$ & $7.40^{\mathrm{cd}}$ & $11.60^{\mathrm{ef}}$ & $19.80^{\text {cdef }}$ & $23.80^{\mathrm{a}}$ & 32.00 \\
\hline $\mathbf{T}_{4}$ & Red Round & $66.40^{\text {defgh }}$ & $143.50^{\mathrm{efg}}$ & $229.00^{\mathrm{ab}}$ & $241.30^{\mathrm{cd}}$ & $7.30^{\mathrm{d}}$ & $13.30^{\text {bcde }}$ & $20.10^{\text {bcde }}$ & $23.00^{\mathrm{abc}}$ & 28.00 \\
\hline $\mathbf{T}_{5}$ & COHBT-68 & $66.80^{\text {defgh }}$ & $129.10^{\mathrm{hi}}$ & $156.80^{f}$ & $196.20^{\mathrm{gh}}$ & $7.10^{\mathrm{de}}$ & $11.00^{f}$ & $19.80^{\text {cdef }}$ & $23.40^{\mathrm{a}}$ & 29.00 \\
\hline $\mathbf{T}_{6}$ & СОНВТ-270 & $48.40^{\text {defgh }}$ & $142.20^{\text {efg }}$ & $189.70^{\mathrm{cb}}$ & $203.10^{\mathrm{efg}}$ & $8.00^{\text {bcd }}$ & $13.10^{\text {bcde }}$ & $20.20^{\mathrm{bcd}}$ & $21.50^{\text {bcdef }}$ & 32.00 \\
\hline $\mathbf{T}_{7}$ & COHBT -262 & $57.30^{\mathrm{gh}}$ & $124.90^{1}$ & $232.00^{\mathrm{ab}}$ & $241.00^{\mathrm{cd}}$ & $7.00^{\mathrm{de}}$ & $13.60^{\mathrm{abcd}}$ & $20.40^{\mathrm{bc}}$ & $23.60^{\mathrm{a}}$ & 30.00 \\
\hline $\mathbf{T}_{8}$ & СОНВТ-217 & $59.10^{\text {efgh }}$ & $136.50^{\mathrm{gh}}$ & $184.70^{\text {cde }}$ & $194.80^{\mathrm{gh}}$ & $7.20 \mathrm{~d}^{\mathrm{e}}$ & $11.60^{\mathrm{ef}}$ & $20.70^{b}$ & $23.10^{\mathrm{ab}}$ & 32.50 \\
\hline $\mathbf{T}_{9}$ & COHBT-70 & $58.80^{\mathrm{h}}$ & $136.70^{\mathrm{gh}}$ & $195.50^{c}$ & $209.60^{e}$ & $10.60^{\mathrm{ab}}$ & $12.00^{\mathrm{def}}$ & $21.80^{\mathrm{e}}$ & $23.80^{\mathrm{a}}$ & 31.00 \\
\hline $\mathbf{T}_{10}$ & COHBT-44 & $82.60^{\mathrm{ab}}$ & $172.70^{\mathrm{ab}}$ & $238.80^{\mathrm{a}}$ & $246.00^{b c}$ & $8.40^{\text {bcd }}$ & $12.80^{\text {cdef }}$ & $20.50^{b c}$ & $22.80^{\mathrm{abcd}}$ & 29.50 \\
\hline $\mathbf{T}_{11}$ & Yellow Round & $70.50^{\text {def }}$ & $163.70^{\mathrm{bc}}$ & $236.80^{\mathrm{a}}$ & $200.00^{\text {efgh }}$ & $8.30^{\mathrm{bcd}}$ & $12.80^{\text {cdef }}$ & $18.30^{\mathrm{i}}$ & $21.20^{\text {def }}$ & 30.00 \\
\hline $\mathbf{T}_{12}$ & COHBT -198 & $73.30^{\text {bcd }}$ & $140.10^{\mathrm{fg}}$ & $186.60^{\text {cde }}$ & $251.80^{\mathrm{ab}}$ & $7.90^{\mathrm{bcd}}$ & $14.00^{\mathrm{abc}}$ & $20.60^{\mathrm{bc}}$ & $20.50^{f}$ & 30.50 \\
\hline $\mathbf{T}_{13}$ & COHBT-209 & $62.30^{\text {efgh }}$ & $137.70^{\mathrm{gh}}$ & $180.70^{\text {cde }}$ & $192.00^{\mathrm{h}}$ & $10.30^{\mathrm{abc}}$ & $13.50^{\mathrm{abcd}}$ & $19.50^{\mathrm{def}}$ & $22.20^{\text {abcde }}$ & 30.50 \\
\hline $\mathbf{T}_{14}$ & COHBT -71 & $70.50^{\text {cde }}$ & $123.10^{\mathrm{i}}$ & $187.90^{\text {cde }}$ & $199.90^{\text {efgh }}$ & $7.60^{\text {cd }}$ & $12.80^{\text {cdef }}$ & $18.40^{\mathrm{hi}}$ & $21.10^{\mathrm{ef}}$ & 29.50 \\
\hline $\mathbf{T}_{15}$ & COHBT -48 & $72.00^{\text {bcd }}$ & $148.40^{\text {ef }}$ & $176.50^{\text {de }}$ & $191.60^{\mathrm{h}}$ & $7.10^{\mathrm{de}}$ & $13.20^{\text {bcde }}$ & $18.50^{\text {ghi }}$ & $21.50^{\text {bcdef }}$ & 31.50 \\
\hline $\mathbf{T}_{16}$ & COHBT-31 & $86.90^{\mathrm{abc}}$ & $151.40^{\mathrm{de}}$ & $181.30^{\text {cde }}$ & $197.80^{\text {efg }}$ & $8.50^{\text {bcd }}$ & $15.30^{\mathrm{a}}$ & $20.40^{\mathrm{bc}}$ & $22.90^{\mathrm{abc}}$ & 31.00 \\
\hline $\mathbf{T}_{17}$ & COHBT-36 & $54.80^{\mathrm{def}}$ & $137.20^{\mathrm{gh}}$ & $227.40^{\mathrm{ab}}$ & $241.20^{\mathrm{cd}}$ & $7.00^{\text {de }}$ & $14.70^{\mathrm{ab}}$ & $19.30^{\text {efg }}$ & $20.80^{\mathrm{ef}}$ & 31.00 \\
\hline $\mathbf{T}_{18}$ & COHBT -199 & $94.00^{\mathrm{a}}$ & $180.20^{\mathrm{a}}$ & $243.00^{\mathrm{a}}$ & $261.10^{\mathrm{a}}$ & $11.70^{\mathrm{a}}$ & $14.10^{\mathrm{abc}}$ & $22.00^{\mathrm{a}}$ & $23.80^{\mathrm{a}}$ & 24.00 \\
\hline $\mathbf{T}_{19}$ & COHBT-208 & $69.90^{\mathrm{de}}$ & $121.80^{\mathrm{i}}$ & $219.20^{b}$ & $235.30^{\mathrm{d}}$ & $8.50^{\text {bcd }}$ & $13.30^{\text {bcde }}$ & $19.40^{\text {def }}$ & $20.90^{\text {ef }}$ & 31.00 \\
\hline $\mathbf{T}_{20}$ & COHBT -206 & $63.80^{\text {defgh }}$ & $98.50^{\mathrm{j}}$ & $172.60^{\mathrm{e}}$ & $179.50^{i}$ & $7.70^{\text {bed }}$ & $12.60^{\text {cdef }}$ & $19.20^{\mathrm{fgh}}$ & $21.40^{\text {cdef }}$ & 30.50 \\
\hline $\mathbf{T}_{21}$ & COHBT -191 & $58.60^{\operatorname{detg}}$ & $150.30^{\mathrm{e}}$ & $229.00^{\mathrm{ab}}$ & $237.00^{\mathrm{cd}}$ & $8.30^{\text {bed }}$ & $14.40^{\mathrm{abc}}$ & $22.50^{\mathrm{a}}$ & $23.40^{\mathrm{a}}$ & 30.50 \\
\hline \multicolumn{2}{|c|}{ Mean } & 69.68 & 141.73 & 203.71 & 217.60 & 7.92 & 12.97 & 20.00 & 22.31 & 30.33 \\
\hline \multicolumn{2}{|c|}{ S.Em \pm} & 2.00 & 6.27 & 10.85 & 12.48 & 0.45 & 0.63 & 0.75 & 0.80 & 1.47 \\
\hline \multicolumn{2}{|c|}{ CD at $5 \%$} & 11.81 & 18.51 & 32.01 & 36.83 & 1.35 & 1.87 & 2.22 & 2.37 & NS \\
\hline \multicolumn{2}{|c|}{$\mathrm{CV}$} & 8.16 & 6.28 & 7.55 & 8.27 & 8.42 & 6.91 & 5.35 & 5.15 & 6.88 \\
\hline
\end{tabular}


Table.2 Variation of cherry tomato genotypes for yield parameters

\begin{tabular}{|c|c|c|c|c|c|c|c|}
\hline Treatment & Genotypes & $\begin{array}{l}\text { No. of flowers } \\
\text { per cluster }\end{array}$ & $\begin{array}{l}\text { No. of fruits per } \\
\text { cluster }\end{array}$ & $\begin{array}{c}\text { Fruit } \\
\text { length } \\
\text { (cm) }\end{array}$ & $\begin{array}{l}\text { Fruit } \\
\text { girth } \\
(\mathrm{cm})\end{array}$ & $\begin{array}{l}\text { Avg. fruit } \\
\text { weight (g) }\end{array}$ & $\begin{array}{c}\text { Fruit yield } \\
\text { per plant } \\
(\mathrm{kg})\end{array}$ \\
\hline $\mathbf{T}_{1}$ & COHBT-253 & $7.30^{\text {cde }}$ & $5.25^{\mathrm{cd}}$ & $3.50 \mathrm{~d}^{\mathrm{ef}}$ & $2.95^{\text {cde }}$ & $26.25^{\mathrm{gh}}$ & $2.00^{b}$ \\
\hline $\mathbf{T}_{2}$ & COHBT -46 & $6.80 \mathrm{~d}^{\mathrm{efg}}$ & $4.00^{f}$ & $3.45^{\operatorname{defg}}$ & $3.95^{\mathrm{a}}$ & $31.55^{\mathrm{e}}$ & $1.30^{\mathrm{fgh}}$ \\
\hline $\mathbf{T}_{3}$ & COHBT-27 & $7.30^{\text {cde }}$ & $4.50^{\mathrm{def}}$ & $3.55^{\text {cdef }}$ & $3.80^{\mathrm{a}}$ & $35.70^{c}$ & $1.30^{\mathrm{fgh}}$ \\
\hline $\mathbf{T}_{4}$ & Red Round & $9.10^{b}$ & $6.55^{\mathrm{b}}$ & $3.50^{\mathrm{def}}$ & $3.40^{\text {abcde }}$ & $20.90^{\mathrm{kl}}$ & $2.10^{\mathrm{ab}}$ \\
\hline $\mathbf{T}_{5}$ & COHBT-68 & $7.00^{\text {defg }}$ & $5.10^{\text {cde }}$ & $3.00^{\mathrm{gh}}$ & $3.00^{\text {cde }}$ & $14.00^{\mathrm{n}}$ & $1.50^{\mathrm{def}}$ \\
\hline $\mathbf{T}_{6}$ & COHBT-270 & $7.20^{\text {cdet }}$ & $5.50^{\mathrm{ced}}$ & $4.00 b^{c}$ & $3.40^{\text {abcde }}$ & $22.75^{\mathrm{J}}$ & $1.00^{1}$ \\
\hline $\mathbf{T}_{7}$ & COHBT -262 & $7.30^{\text {cde }}$ & $4.50^{\mathrm{def}}$ & $1.75^{\mathrm{i}}$ & $1.65^{\mathrm{f}}$ & $3.50^{\mathrm{op}}$ & $1.25^{\mathrm{gh}}$ \\
\hline $\mathbf{T}_{8}$ & COHBT-217 & $6.10^{\mathrm{efg}}$ & $4.00^{f}$ & $3.55^{\text {cdef }}$ & $3.70^{\mathrm{ab}}$ & $23.50^{\mathrm{j}}$ & $1.75^{\mathrm{c}}$ \\
\hline $\mathbf{T}_{9}$ & COHBT-70 & $5.80^{\mathrm{fg}}$ & $4.00^{f}$ & $3.20^{\text {efg }}$ & $3.75^{\mathrm{ab}}$ & $38.90^{b}$ & $2.20^{\mathrm{ab}}$ \\
\hline $\mathbf{T}_{10}$ & COHBT-44 & $6.60^{\text {defg }}$ & $4.00^{f}$ & $3.10^{\mathrm{fgh}}$ & $3.75^{\mathrm{ab}}$ & $26.95^{\mathrm{fg}}$ & $1.40^{\text {efg }}$ \\
\hline $\mathbf{T}_{11}$ & Yellow Round & $7.65^{\mathrm{cd}}$ & $5.25^{\mathrm{cd}}$ & $3.00^{\mathrm{gh}}$ & $2.75^{\mathrm{e}}$ & $20.25^{1}$ & $1.70^{\mathrm{cd}}$ \\
\hline $\mathbf{T}_{12}$ & COHBT -198 & $9.75^{\mathrm{ab}}$ & $6.60^{\mathrm{b}}$ & $5.00^{\mathrm{a}}$ & $4.00^{\mathrm{a}}$ & $43.90^{\mathrm{a}}$ & $2.30^{\mathrm{a}}$ \\
\hline $\mathbf{T}_{13}$ & COHBT-209 & $6.40^{\mathrm{efg}}$ & $4.75^{\mathrm{def}}$ & $3.70^{\mathrm{bcd}}$ & $4.00^{\mathrm{a}}$ & $34.95^{\mathrm{c}}$ & $1.40^{\text {efg }}$ \\
\hline $\mathbf{T}_{14}$ & COHBT -71 & $7.60^{\mathrm{cd}}$ & $4.75^{\mathrm{def}}$ & $3.25^{\text {defg }}$ & $3.10^{\text {bcde }}$ & $15.50^{\mathrm{m}}$ & $1.10^{\mathrm{hi}}$ \\
\hline $\mathbf{T}_{15}$ & COHBT -48 & $8.50^{\mathrm{bc}}$ & $5.75^{\mathrm{bc}}$ & $3.30^{\text {defg }}$ & $3.45^{\mathrm{abcd}}$ & $20.85^{\mathrm{kl}}$ & $1.20^{\text {ghi }}$ \\
\hline $\mathbf{T}_{16}$ & COHBT-31 & $6.80^{\operatorname{defg}}$ & $4.00^{f}$ & $2.70^{\mathrm{h}}$ & $2.85^{\mathrm{de}}$ & $21.70^{\mathrm{k}}$ & $1.15^{\mathrm{hi}}$ \\
\hline $\mathbf{T}_{17}$ & COHBT-36 & $6.40^{\text {efg }}$ & $4.25^{\mathrm{ef}}$ & $4.05^{b}$ & $3.55^{\mathrm{abc}}$ & $25.20^{\mathrm{i}}$ & $1.55^{\mathrm{cde}}$ \\
\hline $\mathbf{T}_{18}$ & СОНВТ -199 & $10.64^{\mathrm{a}}$ & $8.75^{\mathrm{a}}$ & $3.60^{\text {bcde }}$ & $3.45^{\mathrm{abcd}}$ & $33.35^{\mathrm{d}}$ & $2.20^{\mathrm{ab}}$ \\
\hline$T_{19}$ & COHBT-208 & $7.60^{\mathrm{cd}}$ & $5.00^{\text {cde }}$ & $3.30^{\operatorname{detg}}$ & $4.00^{\mathrm{a}}$ & $25.55^{\mathrm{hi}}$ & $2.00^{b}$ \\
\hline $\mathbf{T}_{20}$ & COHBT -206 & $6.00^{\text {efg }}$ & $4.00^{f}$ & $3.35^{\text {defg }}$ & $3.90^{\mathrm{a}}$ & $34.85^{\mathrm{c}}$ & $1.40^{\text {efg }}$ \\
\hline $\mathbf{T}_{21}$ & COHBT -191 & $5.60^{\mathrm{g}}$ & $3.00^{\mathrm{g}}$ & $3.20^{\text {etg }}$ & $3.45^{\mathrm{abcd}}$ & $27.65^{\mathrm{t}}$ & $1.50^{\mathrm{det}}$ \\
\hline \multicolumn{2}{|c|}{ Mean } & 7.30 & 4.90 & 3.38 & 3.42 & 26.08 & 1.58 \\
\hline \multicolumn{2}{|c|}{ S.Em \pm} & 0.48 & 0.31 & 0.14 & 0.22 & 0.94 & 0.09 \\
\hline \multicolumn{2}{|c|}{ CD at $5 \%$} & 1.43 & 0.92 & 0.46 & 0.68 & 2.80 & 0.22 \\
\hline \multicolumn{2}{|c|}{ CV } & 9.30 & 8.96 & 6.55 & 9.53 & 5.24 & 6.61 \\
\hline
\end{tabular}




\section{Acknowledgement}

The authors are highly thankful to the Indian Council of Agricultural Research, New Delhi India and Department of vegetable science College of Horticulture, Bengaluru for providing technical and financial assistance during the research programme.

\section{References}

Alam, M.S., Sultana, N., Ahmad, S., Hossain, M.M. and Islam, A.K.M.A., 2010, Performance of heat tolerant tomato hybrid lines under hot, humid conditions. Bangladesh. J. Agril. Res., 35(3): 367-373.

Anonymous., 2009a., Botanical classification of cherry tomato. ( $w w w$.lose-weightwithus.com/cherry tomatonutrition.html. ).

Anonymous., 2009b., Cherry tomato nutritional information; USDA National Nutritional Database for Standard Reference. (www. Lose- weightwithus.com/cherry tomato- nutrition. Html ).

Deepa, S. and Thakur, M.C., 2008, Evaluation of diallele progenies for yield and its contributing traits in tomato under midhill conditions. Indian J. Hort., 65 (3):297-301.

Ghosh, K.P., Islsm, A.K.M.A., Mian, M.A.K. and Hossain, M. M., 2010, Variability and character association in F2 segregating population of different commercial hybrids of tomato (Solanum lycopersicum L.). J. Appl. Sci. Environ. Manage. 14 (2): 91-95.

Gomathi, S.P. 2008. Development of semi determinate $F_{1}$ hybrids in tomato (Solanum lycopersicum Mill.) with combined resistance to viral disease and nematodes. M.Sc. Thesis, TNAU, Coimbatore.

Kaushik, S. K., Tomar, D. S. and Dixit, A. K.,
2011, Genetics of fruit yield and it's contributing characters in tomato (Solanum lycopersicom). J. Agric. Bio. And Sustainable Dev., 3(10): 209-213.

Kumar, K. J., Trvedi, D. Shrma and Nair, S. K., 2014, Evaluation for fruit production and quality of cherry tomato (Solanum lycopersicum L. Var cerasiforme). Trends in Biosciences, 7 (24):4304-4307.

Mahendrakar, P., Mulge, R. Madalageri,M.B. Patil,M.S., Ravi, B. A. and Chandan, K., 2006, Exploitation of hybrid vigour for growth and yield parameter in tomato. ATSH, 33.

Manna, M. and Paul., A., 2012, Studies on genetic variability and characters association of fruit quality parameters in tomato. Hort. Flora Research Spectrum.,1(2): 110-116.

Mehta, N. and Asati, B. S., 2008, Genetic divergence for fruit characters in tomato (Lycopersicon esculentum Mill.). Agric. Sci. Digest., 28(2): 141-142.

Mohanty, B. K., 2003, Genetic variability, correlation and path coefficient studies in tomato. Indian J. Agril. Res., 37(1):68-71.

Naidu, K. N., 2001, Study of growth, yield and quality attributes of promising genotype of tomato (Lycopersicon esculentum Mill) in Chhattisgarh plains. M.Sc. (Ag.) Thesis, I.G.K.V. Raipur (C.G.).

Nitzsche, P., Tietjen, W., Kline. W. and Garrison. S., 2003. Evaluation of grape and cherry tomatoes in North New Jersey. In: Tomato varieties/ trial reports- 2003. https://njaws.rutgers.edu/.

Prashanth, S. J., 2003, Genetic variability and divergence study in tomato (Lycopersicon esculentum Mill). M. Sc. (Agri.) Thesis, Uni. Agric. Sci., Dharwad (India).

Prema, G., Indiresh, K. M. and Santhosha, H. M., 2011a, Evaluation of cherry tomato 
(Solanum lycopersicum var. cerasiforme) genotypes for growth, yield and quality traits. Asian J. Hort., 6(1): 181-184.

Renuka, D. M., Sadashive, A. T. and Jogi, M., 2017, Genetic variability studies in cherry tomato (Solanum lycopersicum L. var. cerasiforme Mill). Int. J. Curr. Microbiol. App. Sci., 6(10): 2085-2089.

Renuka, D.M., Sadashiva, A.T., Kavita, B.T., Vijendrakumar, R.C. and Hanumanthiah, M.R., 2014, Evaluation of cherry tomato lines (Solanum lycopersicum var. cerasiforme) for growth, yield and quality traits. Plant
Archives, 14(1): 151- 154.

Rick, C. M., 1969, Origin of cultivated tomato and status of the problem. Abstr. XIInternat. Bot. Congr., 180: 39-45.

Singh, P. K. and Gopalkrishnan, T. R., 2000,Variability and heritability estimates in brinjal (Solanum melongena L.). South Indian Hort., 47(1-6): 174-178.

Trivedi, J., 1996, Evaluation of F1 hybrids/varieties of tomato (Lycopersicon esculentum Mill.). M.Sc. (Ag.) Thesis, submitted to I.G.K.V. Raipur (C.G.).

\section{How to cite this article:}

Najibullah Anwarzai, Jyothi Kattegoudar, M. Anjanappa, Meenakshi Sood, B. Anjaneya Reddy and Mohan Kumar. S. 2020. Evaluation of Cherry Tomato (Solanum lycopersicum L. var. cerasiforme) Genotypes for Growth and Yield Parameters. Int.J.Curr.Microbiol.App.Sci. 9(03): 459-466. doi: https://doi.org/10.20546/ijcmas.2020.903.053 